\title{
Cytological Diagnosis and Treatment of Transmissible Veneral Tumor in Dog- A Case Study
}

\author{
Rouf Rashid Dar*, Sheikh Tajamul Islam, Abdul Rouf, John Mohammad Wani, \\ Pooja Dogra, Amir Amin Sheikh, Rohini Gupta, Neeti Lakhani and Mohd Younis Ganaie \\ Department of Veterinary Gynaecology and Obstetrics, International Institute of Veterinary \\ Education and Research (IIVER), Rohtak Haryana-124001, India \\ *Corresponding author
}

\section{A B S T R A C T}

Keywords

Canine

transmissible

venereal tumor,

Serosanguinous,

Bloody discharge,

Cytological

diagnosis.

\section{Article Info}

Accepted:

14 September 2017

Available Online:

10 October 2017
Canine transmissible venereal tumor (CTVT), also known as canine transmissible venereal sarcoma (CTVS), stickers sarcoma and infectious sarcoma is a benign reticuloendothelial tumor of the both male as well as female dog that mainly affects the external genitalia. This tumor was found in male 4 years old Labrador dog. Anamnestic data revealed normal body vitals including temperature of $102^{\circ} \mathrm{C}$ and pulse of $80 /$ minute, except spontaneous bleeding from prepuce and the presence of serosanguinous bloody discharge in the urine since last 6 months. Upon clinical examination, a multilobular typical cauliflower shaped tumerous mass was located on the base of the penile bulb, which actually caused sanguinous discharge. The sample material for cytological diagnostics were taken with the help of impression method and three cytological impression smears were prepared and stained with wrights Giemsa for diagnostic purpose. Results were suggestive of presence of high cellularity, presence of tumor cells which were large round cells with round nucleus, coarse and reticulated chromatin, abundant and lightly basophilic cytoplasm and multiple punctate cytoplasmic vacuoles, all conclusive of the cytological diagnosis of CTVT. After surgical resuction of the mass, medicinal therapy was started by vincrystine sulphate @ $0.025 \mathrm{mg} / \mathrm{kg} \mathrm{BW}$ along with Rantidine, Avil and multivitamin on weekly basis.

\section{Introduction}

Canine Transmissible Venereal Tumor (CTVT) also known as infectious sarcoma, venereal granuloma, transmissible lymphosarcoma or stickers sarcoma, is a benign reticuloendothelial (histiocytic) tumor of the $\operatorname{dog}$ (17) that mainly affects the external genitalia. TVT is located mainly in the mucosa of the external genitalia of both sexes (1). It is located on the base of the penis or prepuce in males, and on the vagina or labia in females. Infection and transmission occurs mainly through intercourse, being more common in young sexually mature animals. Due to exfoliation on affected region from the sick animal, an atypical neoplastic cell infection occurs on healthy individuals. These may grow slowly over years and become invasive, eventually changing to malignant and metastatic.

Upon genitalia examination, males generally have tumors cranially located on the glans, and preputial bulb and mucosa $(7,16)$, with a consequent phimosis. In females, TVT is 
located in the caudal vagina and vaginal vestibule (7), but rarely found in the uterine region. Generally, its projection from the vulva causes deformation of the perineal region without interfering with urination. Ulcerated lesions in male external organs taking place with hemorrhagic discharges usually mystified with urethritis, cystitis and prostatitis. In females, such lesions can cause anemia.

The methods used to treat TVT are cryosurgery, radiotherapy, surgical resection and antineoplastic chemotherapy that is the protocol of choice in routine clinical treatment. Antineoplastic treatment may combine two or more chemotherapeutic agents (for example, vincristine and cyclophosphamide combined with methotrexate), or it can involve a single agent as vincristine (in which case is most effective or doxorubicin).

\section{Materials and Methods}

This tumor was found in male 4 years old male labrador dog, which was reffered to Teaching veterinary clinics at the International Institute of Veterinary Education and Research (IIVER), Rohtak Haryana. According the anamnestic data, there were no visible changes in general body condition, except of preputial sanguinous discharge and presence of blood in the urine since last 6 months along with sniffing and leaking in the genital area. The dog has normal behavior and apatite, body temperature was $102^{\circ} \mathrm{C}$, pulse was $80 /$ minute, respiration $19 /$ minute. The consumption of water and diuresis were normal. Upon clinical examination, a multilobular typical cauliflower shaped tumorous mass on mucosa of penile bulb (2, 8) was found (Figure 1).

The samples of lobular tumorous mass, located in the penile bulb, were taken with imprint method. Cytological smares were prepared with wrights giemsa. Microscopic Cytological evaluation (Wrights Giemsa, 100X) showed high cellularity and presence of numerous tumor cells with numerous spherical nuclei along with chromatin granules and multiple vacuolization in cytoplasm (3), confirmed as transmissible venereal tumor. Injection Cefataxime @ $10 \mathrm{mg} / \mathrm{kg}$. bwt. was administered intravenously for three days. Vincristine sulfate was administered weekly @ 0.025 $\mathrm{mg} / \mathrm{kg}$, intravenously for three weeks along with supplementation of Tribivet, Aciloc and Avil $1 \mathrm{ml}$ each SID for 5 days. Condition subsided after the first dose itself.

\section{Results and Discussion}

The TVT is a cancer that affects mainly stray dogs, mixed breed, with a mean age of three to eight years, i.e., their active sexual cycle, being intercourse the main form of transmission. The tumor is often found in the genital regions, but can occur in other extragenital regions $(12,13)$. In this present case report the site of the tumor was the external genitalia of a male dog, forming a rigid cauliflower shaped mass without breaking skin. CTVT has many similarities with other round cell tumors. Regular approach and exact differential diagnosis is very useful for further treatment and expecting eventual recurrence. Cytological examination is valuable for diagnosis of round cell tumors, because they do not always have clear architectural features. The most important morphologic aspects of diagnostic opinion come from individual cell morphology using imprint method. CTVT cells are large round cells with round nucleus (Figure 1A), increased nuclear to cytoplasmic ratio $(4,5,6)$ (Figure 3B), coarse chromatin (Figure 3A), one to two prominent nucleoli, and lightly basophilic vacuolated cytoplasm (Figure 2B). 
Fig.1 Penile bulb of dog showing firm, palpable multinodular cauliflower shaped tumerous mass with hemorrgahic foci (Wrights Giemsa, 100X)
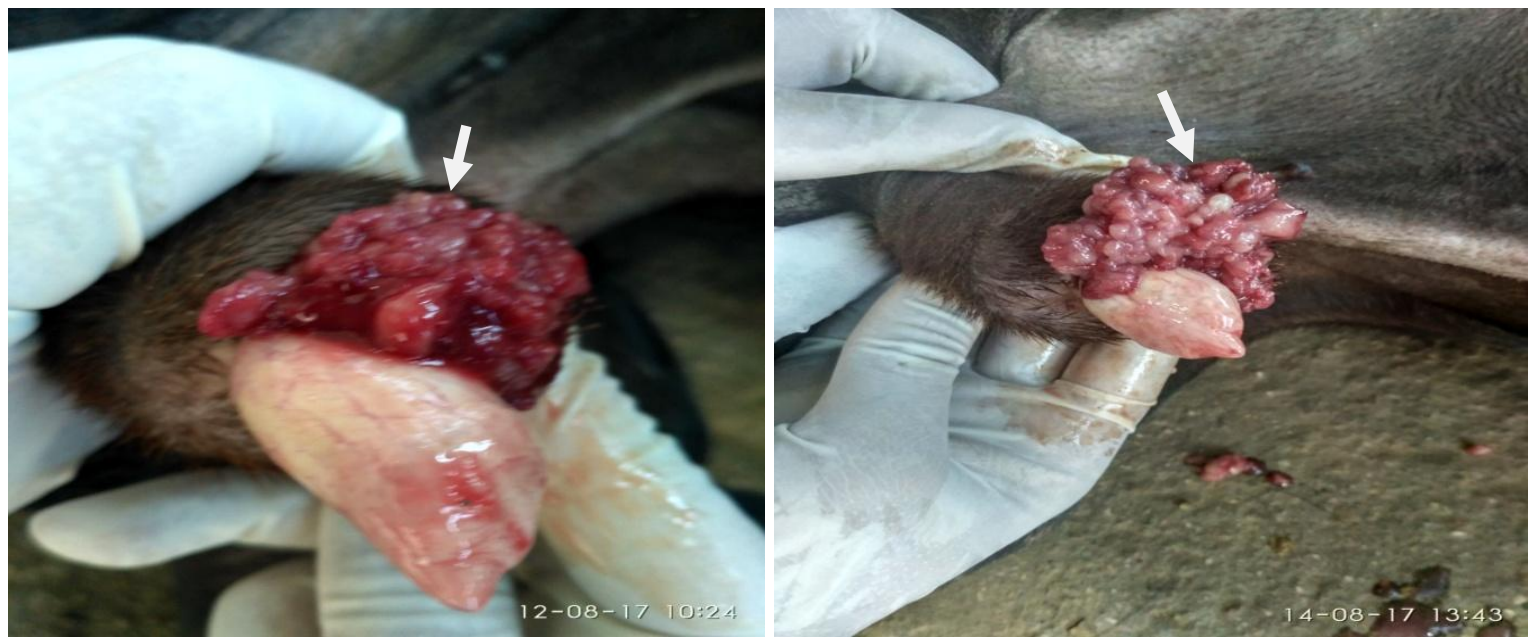

Fig.2 Penile tumorous mass of dog showing sheet of TVT cells (A) with lightly basophilic vacuolated cytoplasm (B). (Wrights Giemsa, 100X)

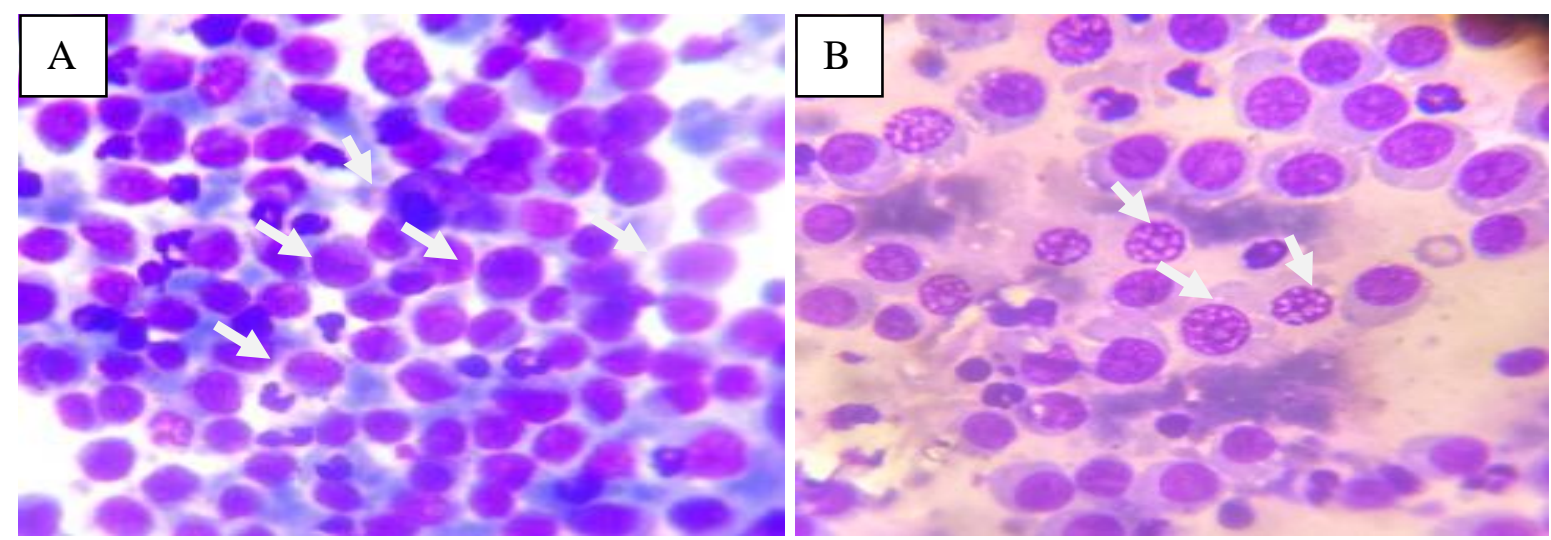

Fig.3 TVT cells with nucleus showing coarse and reticulated chromatin (A) and increased nuclear to cytoplasmic ratio (B) (Wrights Giemsa, 100X)

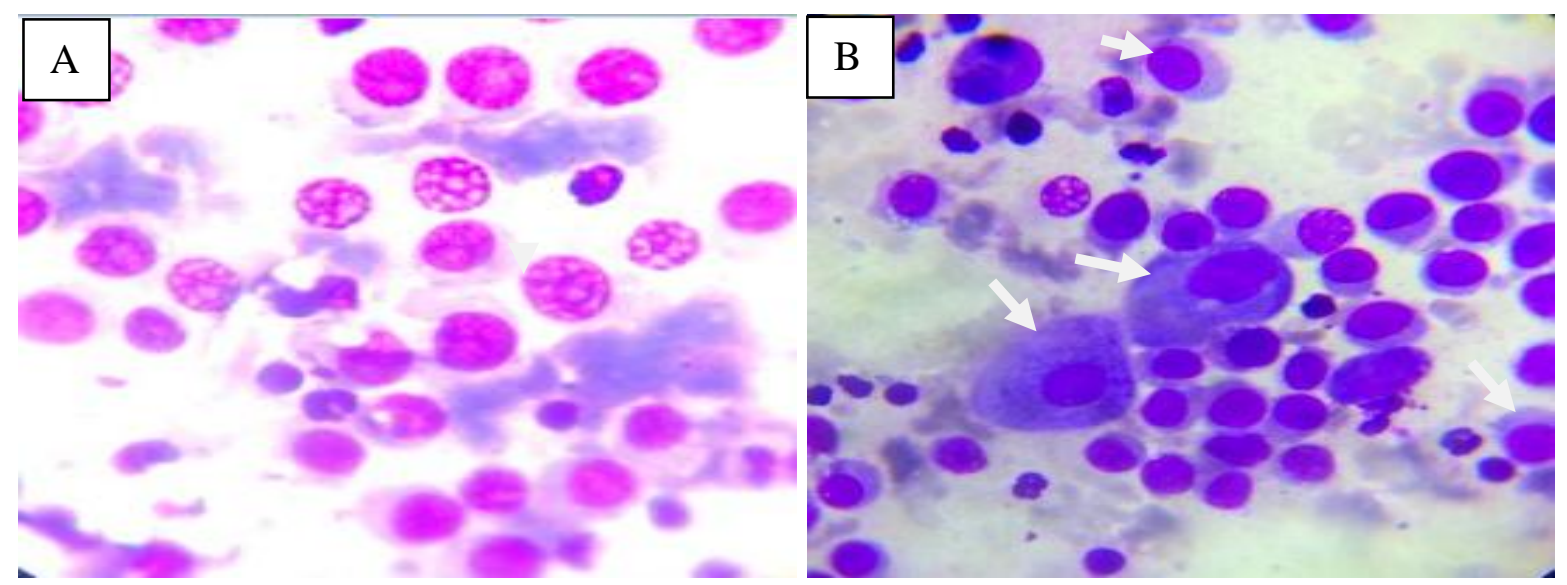


Several treatments including surgery, radiotherapy, immunotherapy, biotherapy and chemotherapy have been applied for TVT (14, $15,16)$. Chemotherapy has been shown to be the most effective and practical therapy, with vincristine sulfate being the most frequently used drug. Vincristine (Cytocristin) is administered weekly at a dose of 0.025 $\mathrm{mg} / \mathrm{kg}$, IV. The involution of the lesions is gradual, although it is particularly noticeable and significant at the beginning of the treatment. Complete remission usually takes 2 to 8 injections and occurs in more than $90 \%$ of the treated cases (unpublished observation). A cure rate approaching $100 \%$ is achieved in cases treated in the initial stages of progression, especially in cases of less than 1 year duration. Cytostatic agents, such as vincristine, can cause myelosuppression and gastrointestinal effects resulting in leucopenia $(9,10,11)$ and vomiting in 5 to $7 \%$ of the patients. Paresis has also been described as a side effect due to peripheral neuropathy. A complete white blood cell count is, therefore, recommended prior to each administration. When the white blood cell count is below $4,000 \mathrm{~mm}^{3}$ further administration should be delayed 3 to 4 days and the dose of vincristine can be reduced to $25 \%$ of the initial dose. The most frequent complication of vincristine treatment is the occurrence of local tissue lesions caused by extravasation of the drug during IV application resulting in the development of necrotic lesions with crusts. Other chemotherapeutic agents indicated for TVT treatment include cyclophosphamide (5 $\mathrm{mg} / \mathrm{kg}$, PO, for 10 days as a single drug therapy or given in association with prednisolone, $3 \mathrm{mg} / \mathrm{kg}$, for 5 days); also, weekly vinblastine $(0.1 \mathrm{mg} / \mathrm{kg}$, IV during 4 to 6 weeks $)$, methotrexate $(0.1 \mathrm{mg} / \mathrm{kg}, \mathrm{PO}$, every other day) or a combination of the 3 drugs. However, there is no apparent advantage in the combination of chemotherapy over using vincristine alone. Many studies have demonstrated that the administration of vincristine associated with ivermectin has shown satisfactory results, due to synergy between these two drugs Thus, the protocol used in the case of vincristine, association with ivermectin was effective in eliminating cancer of the penis and prepuce since the amount of the chemotherapeutic applications has been reduced to four weeks, a significant finding which promoted a decrease in the number of administrations, faster recovery patient and reduced cost of treatment.

TVT may be solitary or multiple and are almost always located on the external genitalia. The tumor is transplanted from site to site and from dog to dog by direct contact with the mass. They may be transplanted to adjacent skin and oral, nasal, or conjunctival mucosa. The tumor may arise deep within the preputial, vaginal, or nasal cavity and be difficult to see during cursory examination. This may lead to misdiagnosis if bleeding is incorrectly assumed to be hematuria or epistaxis from other causes. Cytological examination is valuable for diagnosis of round cell tumors. The most important morphologic aspects of diagnostic opinion using impression smear method are round tumour cells with round nucleus, increased nuclear to cytoplasmic ratio, coarse chromatin, one to two prominent nucleoli, and lightly basophilic vacuolated cytoplasm. Chemotherapy has been shown to be the most effective and practical therapy, with vincristine sulfate being the most frequently used drug.

\section{References}

1. Bloom, F., Paff G.H., Noback, C.R. (1951). The transmissible venereal tumor of the dog; studies indicating that the tumor cells are mature end cells of reticulo-endothelial origin. Am J Pathol., 27 (1): 119-139.

2. Das, U., Das, A.K. (2000). Review of canine transmissible venereal sarcoma. Veterinary 
Research Communications, 24 (8): 545-556.

3. Raskin, Rose E., Meyer, D.J. (2010). Canine and feline cytology: A color atlas and interpretation guide, Second edition, SaundersElsevier.

4. Park, M.-S., Kim, Y., Kang, M.-S., Oh, S.-Y., Cho D.-Y., Shim, N.-S., Kim, D.-Y. (2006). Disseminated transmissible venereal tumor in a dog. J Vet Diagn Invest. (18): 130-133.

5. Stockmann, D., Ferrari, H.F., Andrade, A.L., Lopes, R.A., Cardoso, T.C., Luvizotto Maria, C.R. (2011). Canine transmissible venereal tumors: Aspects related to programmed cell death. Braz J Vet Pathol., 4 (1): 67-75.

6. Do Amaral Anne Santos, Bassani-Silva, S., Ferreira I., da Fonseca L.S., de Andrade F.H.E., Gaspar L.F.J., Rocha N.S. (2007). Cytomorphological characterization of transmissible canine venereal tumor. PRCV, 102 (563-564): 253-260.

7. Nak, D; Nak, Y; Cangul, IT; Tuna, B (2005). A Clinicopathological study on the effect of vincristine on Transmissible Venereal Tumour in dogs. Journal of Veterinary Medicine. A, Physiology, pathology, clinical medicine, 52, 366-370.

8. Purohit, GN (2008). Canine Transmissible Venereal Tumor: A review. The Internet Journal of Veterinary Medicine, 6 (1).

9. Silva, MCV; Barbosa, RR; Santos, RC; Chagas, RSN; Costa, WP (2007). Avaliação epidemiológica, diagnóstica e terapêutica do tumor venéreo transmissível (TVT) na popula- ção canina atendida no hospital veterinário da UFERSA. Acta Veterinaria Brasílica, 1(1), 28-32.

10. Sousa, J; Saito, V; Nardi, AB; Rodaski, S; Guérios, SD; Bacila, M (2000). Característicase incidência do tumor venéreo transmissível (TVT) em cães e eficiência da quimioterapia e outros tratamentos. Archives of Veterinary Science, 5, 41-48.

11. Gaspar, LFJ; Amaral, AS; Bassani-Silva, S; Rocha, NS (2009). Imunorreatividade à glicoproteína-P no tumor venéreo transmissível canino. Veterinária em Foco, 6(2), 138-146.

12. Das, U; Das, AK (2000). Review of Canine Transmissible Venereal Sarcoma. Veterinary Research Communications, 24, 545-556.

13. Stockmann, D; Ferrari, HF; Andrade, AL; Lopes, RA; Cardoso, TC; Luvizotto, MCR(2011). Canine Transmissible Venereal Tumors: aspects related to programmed cell death. Brazilian Journal of Veterinary Pathology, 4(1), 67-75.

14. Rogers, K.S. (1997) Transmissible Venereal Tumor. Compendium on Continuing Education for the Practising Veterinarian, 19, 1036-1045.

15. Weir, E.C., Pond, M.J., Duncan, J.R., et al. (1987) Extragenital Located TVT Tumor in the Dog. Literature Review and Case Reports. Journal of the American Animal Hospital Association, 14, 532-536.

16. Johnson, C.A. (1994) Genital Infections and Transmissible Venereal Tumor. In: Nelson, R.W. and Couto, C.G., Eds., Fundamentos de Medicina Interna de Pequenos Animais, Guanabara Koogan, Rio de Janeiro, 525.

17. Brown, N.O., MacEwen, E.G. and Calvert, C.A. (1981) Transmissible Venereal Tumor in the Dog. California Veterinary, 3, 6-10.

18. Higgins, D.A. (1966) Observations on the Canine Transmissible Venereal Tumor as Seen in the Bahamas. Veterinary Record, 79, 67-71.

\section{How to cite this article:}

Rouf Rashid Dar, Sheikh Tajamul Islam, Abdul Rouf, John Mohammad Wani, Pooja Dogra, Amir Amin Sheikh, Rohini Gupta, Neeti Lakhani and Mohd Younis Ganaie. 2017. Cytological Diagnosis and Treatment of Transmissible Veneral Tumor in Dog- A Case Study. Int.J.Curr.Microbiol.App.Sci. 6(10): 1365-1369. doi: https://doi.org/10.20546/ijcmas.2017.610.160 